\title{
SYNTHESIS OF NEW ORGANOSELENIUM COMPOUNDS: CHARACTERIZATION AND BIOLOGICAL STUDIES
}

\author{
Nimra Naz', Saima Saqib³, Rizwan Ashraf', Muhammad Irfan Majeed ${ }^{1}$, Muhammad Adnan Iqbal,2,* \\ ${ }^{1}$ Department of Chemistry, University of Agriculture, Faisalabad-38040, Pakistan \\ ${ }^{2}$ Organometallic and Coordination Chemistry Laboratory, Department of Chemistry, \\ University of Agriculture, Faisalabad, Pakistan \\ ${ }^{3}$ Government Postgraduate College for Women, Samanabad-Lahore, Pakistan \\ adnan.iqbal@uaf.edu.pk
}

\begin{abstract}
Two new organoselenium analogs, (3,3'-(1,2-phenylenebis(methylene))bis(2-selenoxo-2,3dihydro- $1 H$-imidazole-3,1-diyl))bis(methylene) dibenzoate (III) and 3,3'-(1,2-phenylenebis(methylene)) bis(1-benzyl-1H-imidazole-2(3H)-selenone) $(\mathbf{V})$, were derived from newly synthesized organic salts $1,1^{\prime}-$ (1,2-phenylenebis(methylene))bis(3-(2-phenoxyacetyl)- $1 H$-imidazol-3-ium) chloride (II) and 1,1'-(1,2phenylenebis(methylene))bis(3-benzyl-1 $H$-imidazol-3-ium) chloride (IV), and each was characterized by various analytical techniques, such as Fourier-Transform Infrared Spectroscopy (FT-IR), UV-visible, and Nuclear Magnetic Resonance (NMR) spectroscopy, as well as Ultra-high performance liquid chromatography mass spectrometry/Photodiode array (UHPL-MS/PDA). All synthesized compounds were tested for their antioxidant and anticancer potential. Very good radical scavenging results were obtained for salts II and IV, with cell viability values of $84.6 \pm 3.5$ and $56.7 \pm 5.5 \%$, respectively, compared to their organoselenium adducts. All synthesized products showed significant activity against MCF-7 breast cancer cells, but compounds II and III showed better results, with cell viability values of $40.5 \pm 2.0 \%$ and 34.4 $\pm 1.5 \%$, respectively.
\end{abstract}

Keywords: $N$-heterocyclic carbine; selenium; organoselenium; antioxidant; anticancer

\section{СИНТЕЗА НА НОВИ ОРГАНОСЕЛЕНСКИ СОЕДИНЕНИЈА: КАРАКТЕРИЗАЦИЈА И БИОЛОШКИ ИСПИТУВАЊА}

Два нови органоселенски аналози, (3,3'-(1,2-фениленбис(метилен))бис(2-селеноксо-2,3дихидро-1H-имидазол-3,1-диил))бис(метилен) дибензоат (III) и 3,3'-(1,2-фениленбис(метилен))бис (1-бензил-1H-имидазол-2(3H)-селенон) $(\mathbf{V})$, беа дериватизирани од новосинтетизирани органски соли 1,1'-(1,2-фениленбис(метилен))бис(3-(2-феноксиацетил)- $1 H$-имидазол-3-иум) хлорид (II) и 1,1'-(1,2-фениленбис(метилен))бис(3-бензил- 1 H-имидазол-3-иум) хлорид (IV). Секој од нив беше карактеризиран со разни аналитички техники: фуриеова трансформна инфрацрвена спектроскопија (FT-IR), UV-видлива и нуклеарна магнетна резонантна (NMR) спектроскопија, како и ултра-високоефикасна хроматографија со масена спектрометрија/низа од фотодиоди (UHPL-MS/PDA). Сите синтетизирани соединенија беа тестирани за нивните антиоксидациски и антиканцерогени потенцијали. Многу добри резултати во однос на уништувачката способност на радикали беа добиени за солите II и IV, со вредности на клеточна животоспособност, соодветно, од $84.6 \pm 3.5$ и $56.7 \pm 5.5 \%$, споредено со нивните органоселенови адукти. Сите синтетизирани соединенија покажуваат значајна активност против клетките MCF-7 на рак на дојка, меѓутоа соединенијата II и III покажуваат подобри резултати каде вредностите на клеточната животоспособност, се соодветно $40,5 \pm 2,0 \%$ и $34,4 \pm 1,5 \%$.

Клучни зборови: $N$-хетроцикличен карбен; селен; органоселен; антиоксидациско средство; антиканцерогено средство 


\section{INTRODUCTION}

Carbenes contain a divalent neutral carbon atom that is surrounded by six electrons. Four out of these six electrons are involved in $\sigma$-bonding, while two of these electrons exist as a lone pair on the carbon atom $[1,2]$. Since they do not follow the octet rule, they are considered intermediates [3]. In $N$-heterocyclic carbenes, the carbene center takes advantage of the $\pi$-electron-donating and $\sigma$ electron-withdrawing character of the neighboring nitrogen atoms and becomes an electron-rich nucleophilic species. Attributed to their strong $\sigma$ electron-donating properties, NHC ligands can form strong bonds with metal centers [4]. The steric and electronic properties of the NHC ligands can be tuned easily. The steric properties depend on the type of $N$-substituents, while the electronic structure can be altered by changing the type of heterocyclic ring or its substituents [5].

Selenium was discovered in 1817 by Berzelius, a Swedish chemist [6]. Selenium is an essential micronutrient for bacteria, humans and animals, and it plays a significant role in many cellular processes [7] making it an essential trace element for biological functions [8]. It is important for the upkeep of several cellular functions in living bodies. Particularly in humans, selenium is essential for the synthesis of at least 25 selenoproteins, which include iodothyronine deiodinase (ID), glutathione peroxidase (GPx) and thioredoxin reductase (TrxR) families [9].

All elemental forms of selenium are highly reactive towards reagents, so they can be incorporated into organic compounds. Some electrophilic or nucleophilic reagents can be used to introduce selenium into organic compounds $[10,11]$. Organoselenium compounds are considered very important in ligand chemistry, biochemistry, catalysis, semiconducting materials, and pharmaceuticals $[12,13]$. Selenium compounds are good anticancer, anti-inflammatory, antioxidant and antiviral agents [14-16]. In a complex, when selenium is near the heteroatom, it contributes to the intermo- lecular and intramolecular interactions. These interactions stabilize the organoselenium complex and sometimes also contribute to the biological activity of these compounds [17].

Organoselenium compounds have great potential as antioxidants [18]. Selenium controls the function of the GPx enzyme, which is involved in antioxidant activity. GPx neutralizes reactive oxygen species in order to reduce the oxidative stress, thus protecting the cellular integrity [19]. Selenium compounds are important in the maintenance of the redox balance of the cellular environment. On the other hand, selenium levels that are higher than the homeostatic requirements are toxic for living organisms. This is because organic or inorganic selenium compounds act as electrophiles, which oxidize high and low molecular weight thiols and cause oxidative stress [9].

When the selenium compounds are combined with some cytotoxic drug, they have tremendous chemotherapeutic and antitumor efficacy. The selenium compound diphenylmethyl selenocyanate (DMSE) sensitizes tumor cells and can induce apoptosis alone or in combination with cyclophosphamide [20]. Therefore, selenium and organoselenium compounds are now being used as antioxidants and anticancer agents. The present study was done with the hope of synthesizing new $N$ heterocyclic complexes and organoselenium products to obtain better antioxidant and anticancer agents. The selenium compounds were synthesized from imidazolium salt precursors and were evaluated for their antioxidant and anticancer activity.

\section{RESULTS AND DISCUSSION}

\subsection{Synthesis}

First, efforts were made to prepare $\mathrm{N}$ alkylated imidazole by reaction of imidazole and phenoxyacetyl chloride in dimethyl sulfoxide (DMSO) in the presence of a strong base (KOH). The following reaction was predicted (Scheme 1).

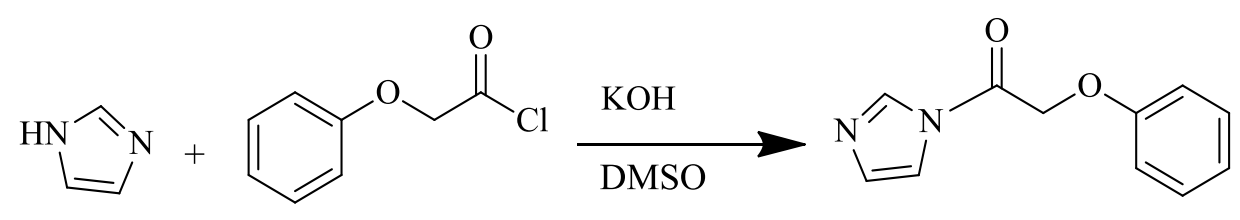

A

Scheme 1. Attempt to synthesize the step I product (intermediate) for the synthesis of salts 
Despite several attempts, product A given in Scheme 1 could not be obtained. Therefore, it was suggested that the given pathway is not suitable for the formation of the product and some other procedure should be followed. Furthermore, it was speculated that in the presence of a strong base, the carbonyl group reacts with imidazole; hence, the required product was not formed [21]. Product I was designed (Scheme 2) because it could lead to the formation of azolium salts II and IV. Salt IV was found to be very hygroscopic since it absorbed onto the filter paper within three days. Furthermore, organoselenium products III and $\mathbf{V}$ were synthesized by incorporation of selenium into II and IV. The pathway for the synthesis of all the products is given in Scheme 2.

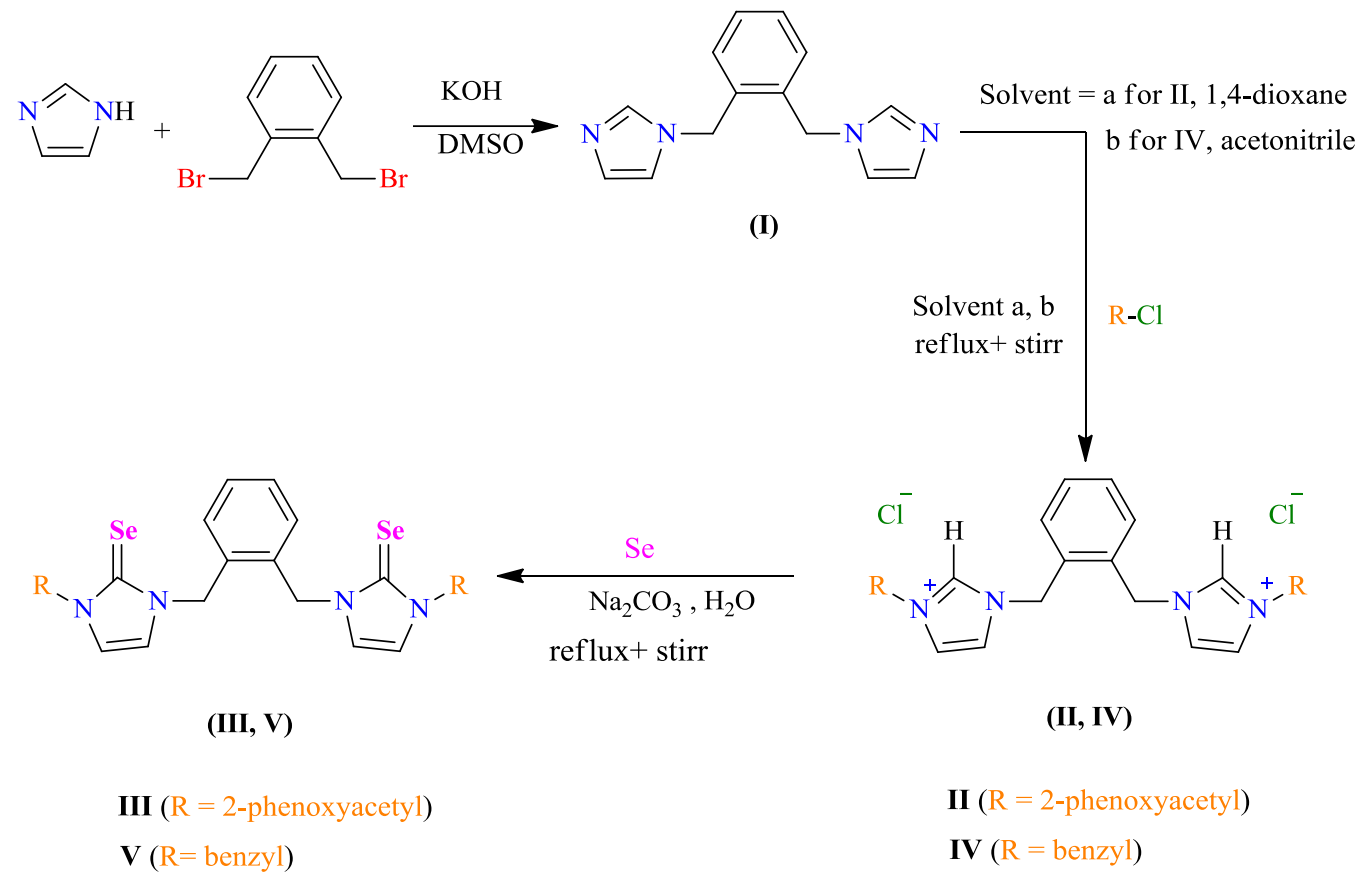

Scheme 2. Synthesis of azolium salts II and IV and the respective organoselenium compounds III and $\mathbf{V}$

\subsection{Characterization}

Strong electrostatic forces exist between the molecules of ionic compounds, leading to higher melting points. In organic compounds, polarity and $\mathrm{H}$-bonding are the major causes of the higher melting points. For the synthesized products, the boiling point of II ranged from $143^{\circ} \mathrm{C}$ to $145^{\circ} \mathrm{C}$. After selenium incorporation, liquid salt II was converted into solid organoselenium product III, with a melting point of $234-236{ }^{\circ} \mathrm{C}$. The substantial change in the state of the product while going from II to III indicated the formation of a new product. For product IV, the melting point range was 235$237{ }^{\circ} \mathrm{C}$, while for its respective organoselenium compound $\mathbf{V}$ it was $162-164{ }^{\circ} \mathrm{C}$. This reduction in melting point lead to the product changing its nature from polar IV to non-polar $\mathbf{V}$.

The $\lambda_{\max }$ for product II was $300 \mathrm{~nm}$, while for organoselenium compound III it was $330 \mathrm{~nm}$ (UPLC-PDA/UV, $223.8 \mathrm{~nm}$ and $260.5 \mathrm{~nm}$, Fig. 1). In addition, the absorption pattern above $480 \mathrm{~nm}$ was similar. Salt IV had an absorption maximum at $330 \mathrm{~nm}$, while its respective selenium compound $\mathbf{V}$ had an absorption maximum at $350 \mathrm{~nm}$ (UPLCPDA/UV, $260.5 \mathrm{~nm}$ and $227.3 \mathrm{~nm}$, Figure 2, Supplementary file, Figs. S1-S2). Furthermore, the absorption pattern for each salt was different from its resulting organoselenium product, possibly indicating a successful synthesis.

In the region of $1400-1750 \mathrm{~cm}^{-1}$ in the Fourier-Transform Infrared (FT-IR) spectra, the vibrational bands of the ligands (Figs. S3, S5) were different from the vibrational bands of the $\mathrm{Se}-\mathrm{NHC}$ compounds (Figs. S4, S6) $[18,21,22]$. The attachment of selenium was confirmed by the peak at around $1457 \mathrm{~cm}^{-1}$, which was given by selenium. A peak appeared at $1235 \mathrm{~cm}^{-1}$ in the spectrum of product III, which was due to the $\mathrm{C}=\mathrm{Se}$ stretching [22]. The phenolic $\mathrm{C}-\mathrm{O}$ peak shifted from 1295 $\mathrm{cm}^{-1}$ to $1291 \mathrm{~cm}^{-1}$. There were some new bands in the range of $700-1100 \mathrm{~cm}^{-1}$, which were not present in the spectrum of the ligand. Furthermore, $\mathrm{CH}_{2}$ bending, which is at $1490 \mathrm{~cm}^{-1}$ in Figure S3, 
shifted to $1440 \mathrm{~cm}^{-1}$ in the organoselenium compounds. This shifting of the band up to $50 \mathrm{~cm}^{-1}$ indicates that $\mathrm{CH}_{2}$ was no longer involved in the conjugation. The multiple broad peaks from 2600 to $3400 \mathrm{~cm}^{-1}$ due to the azolium ion (Fig. S5) disappeared in the spectrum of product V (Fig. S6), which indicates the attachment of selenium. This was further confirmed from the band at $1457 \mathrm{~cm}^{-1}$, which exhibits the presence of selenium. There was a negative shift for the $\mathrm{CH}_{2}$ bending peak, which moved from $1574 \mathrm{~cm}^{-1}$ to $1507 \mathrm{~cm}^{-1}$, showing that the conjugation disappeared as the lone pair of electrons of the carbene made a bond with selenium. For the aromatic amine, the band shifted from $1295 \mathrm{~cm}^{-1}$ to $1235 \mathrm{~cm}^{-1}$.

In the ${ }^{1} \mathrm{H}$ NMR spectrum of product III (Fig. S7), the singlet peak at $3.37 \mathrm{ppm}$ is given by the methylene protons [23]. This upfield value is due to the presence of the $\mathrm{CH}_{2}$ between the two rings. The triplet at $6.93-6.96 \mathrm{ppm}$ is due to two aromatic $\mathrm{CH}$ groups. The multiplet at 7.28-7.32 ppm shows the presence of a benzene ring in the structure. The absence of a peak at around 8.6-9.5 ppm shows the attachment of selenium on the carbene carbon of the imidazole ring [24]. The ${ }^{1} \mathrm{H}$ NMR spectrum of product $\mathbf{V}$ (Fig. S8) shows a signal at $3.38 \mathrm{ppm}$, which is given by $\mathrm{CH}_{2}$. The singlet at $7.09 \mathrm{ppm}$ and the multiplet at 7.31-7.28 ppm belong to benzene and imidazole rings, respectively. The absence of a peak between $8.6 \mathrm{ppm}$ and $9.5 \mathrm{ppm}$ shows that delocalization of the imidazole ring electrons disappeared, indicating that selenium is attached to the carbene center. In the ${ }^{13} \mathrm{C}$ NMR spectrum of the organoselenium compounds, the peak at around $163.1 \mathrm{ppm}$ is due to the $\mathrm{C}-\mathrm{Se}$ bond, which indicates the formation of the expected organoselenium products [21,22].

Ultra-performance liquid chromatographymass spectrometry/photodiode array (UHPLCMS/PDA) analysis was carried out to assess the ionic molecular peaks of each Se-NHC compound (III and V). The molecular masses were found to be close to the proposed molecular structures. The spectral features are shown in Figures 1-2.

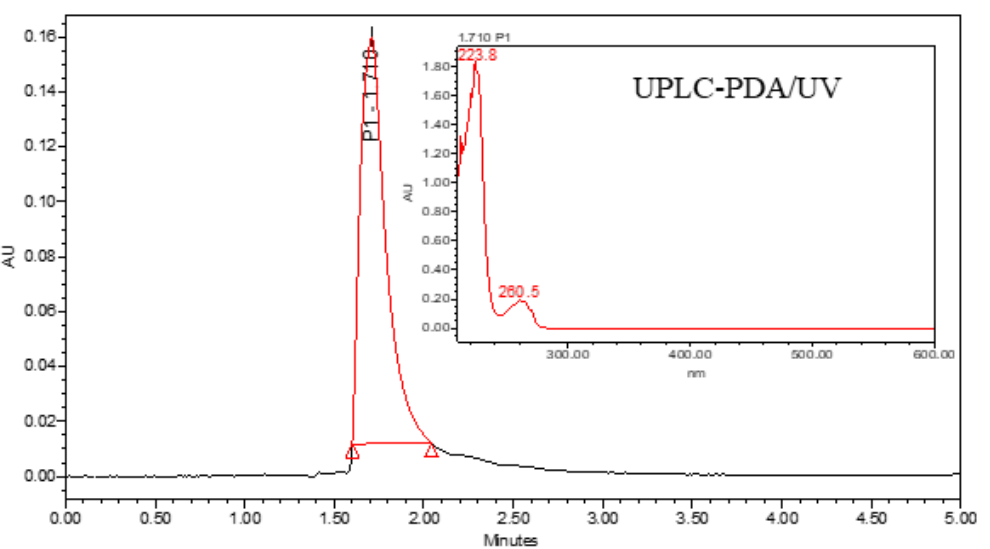

(a)

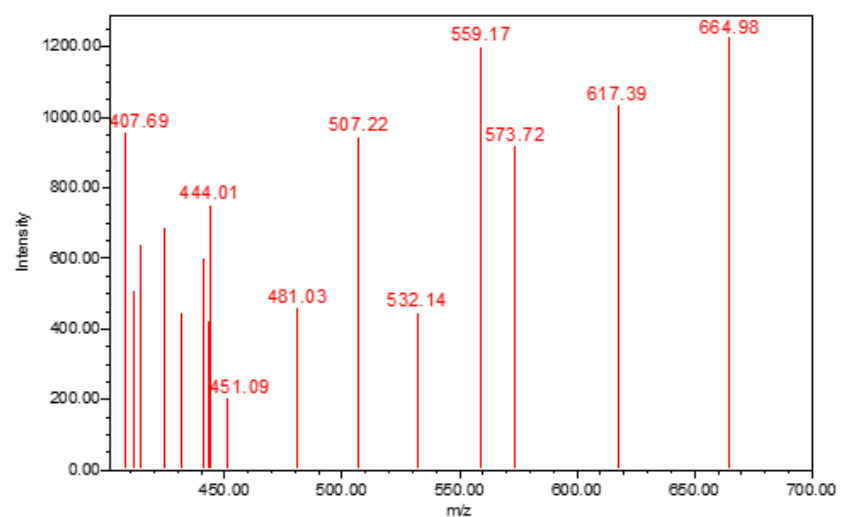

(c)

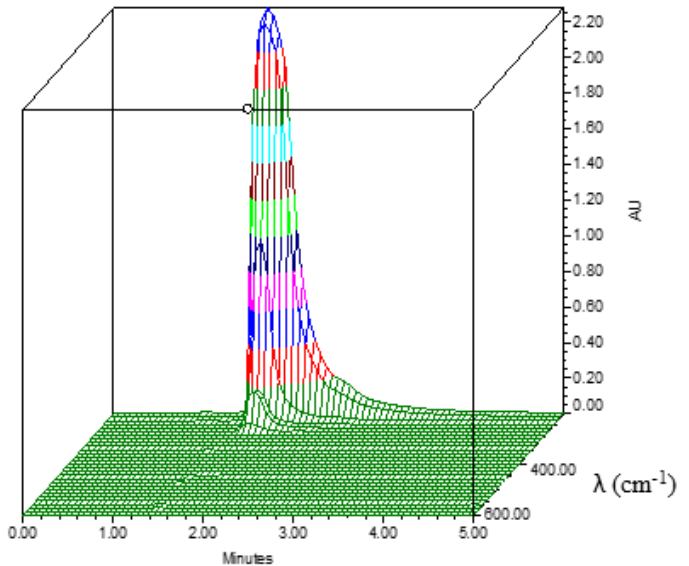

(b)

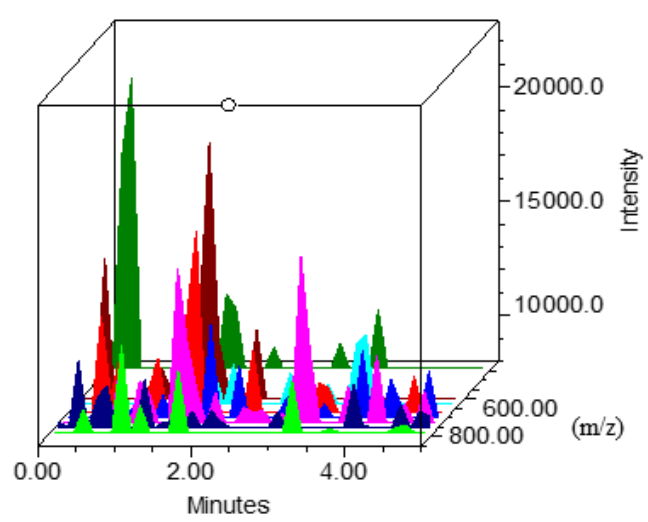

(d)

Fig. 1. Ultra-high performance liquid chromatography-mass spectrometry/photodiode array (UPLC-MS/PDA) analysis of Se-NHC compound III. a) Major UPLC peak of compound III, and the window labelled with UPLC-PDA/UV indicates a simultaneous UV spectrum of the UPLC peak for compound III. b) 3D plot of time, intensity, and wavelength. c) Molecular ionic peaks of MS and d) 3D plot of time, intensity, and $\mathrm{m} / \mathrm{z}$, ratio. 


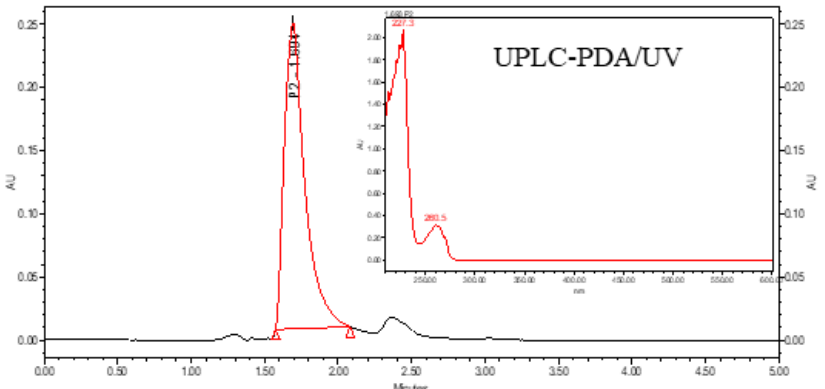

(a)

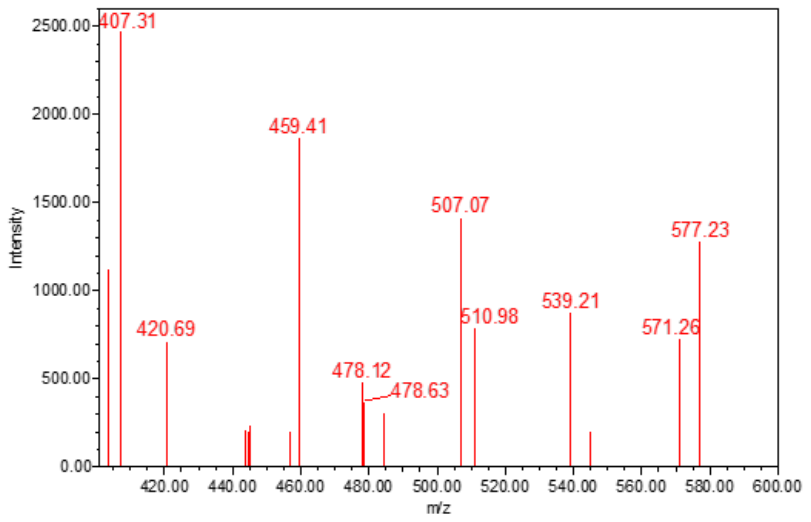

(c)

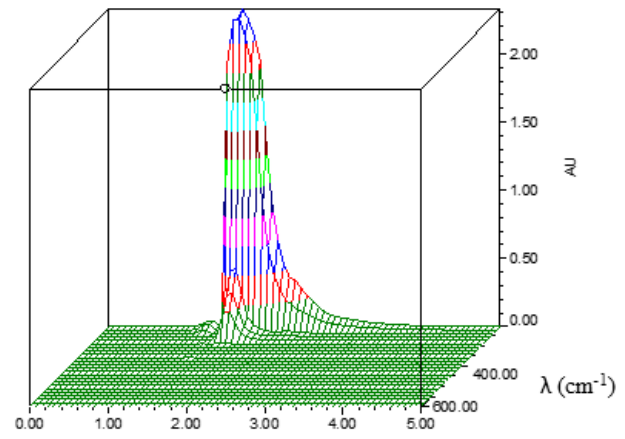

(b)

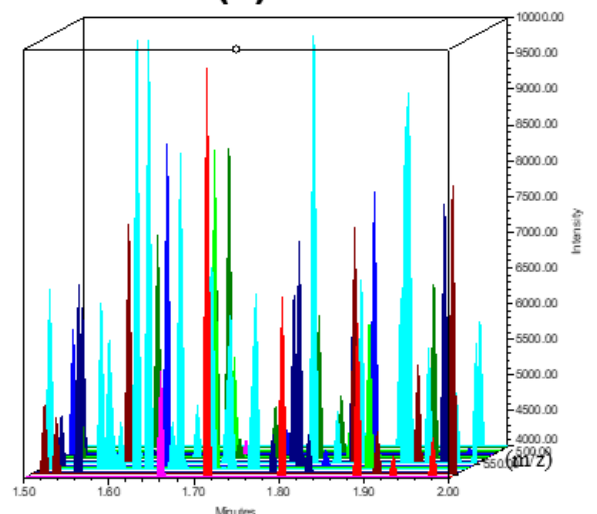

(d)

Fig. 2. Ultra-high performance liquid chromatography-mass spectrometry/photodiode array (UPLC-MS/PDA) analysis of Se-NHC compound $\mathbf{V}$. a) Major UPLC peak of compound $\mathbf{V}$, and the window labelled with UPLC-PDA/UV indicates a simultaneous UV spectrum of the UPLC peak for compound V. b) 3D plot of time, intensity, and wavelength. c) Molecular ionic peaks of MS and d) 3D plot of time, intensity, and $\mathrm{m} / \mathrm{z}$, ratio.

\subsection{Biological activity}

\subsubsection{Antioxidant activity}

The antioxidant activity of the synthesized compounds is given in Figure 3. The radical scavenging activity of a compound depends upon the electron rich environment in the scavenging molecule or the delocalization of the free electrons over the entire molecule [25]. Figure 3 shows a comparison of the antioxidant activity of the synthesized compounds. It demonstrates that salts are more potent antioxidants than their organoselenium compounds.

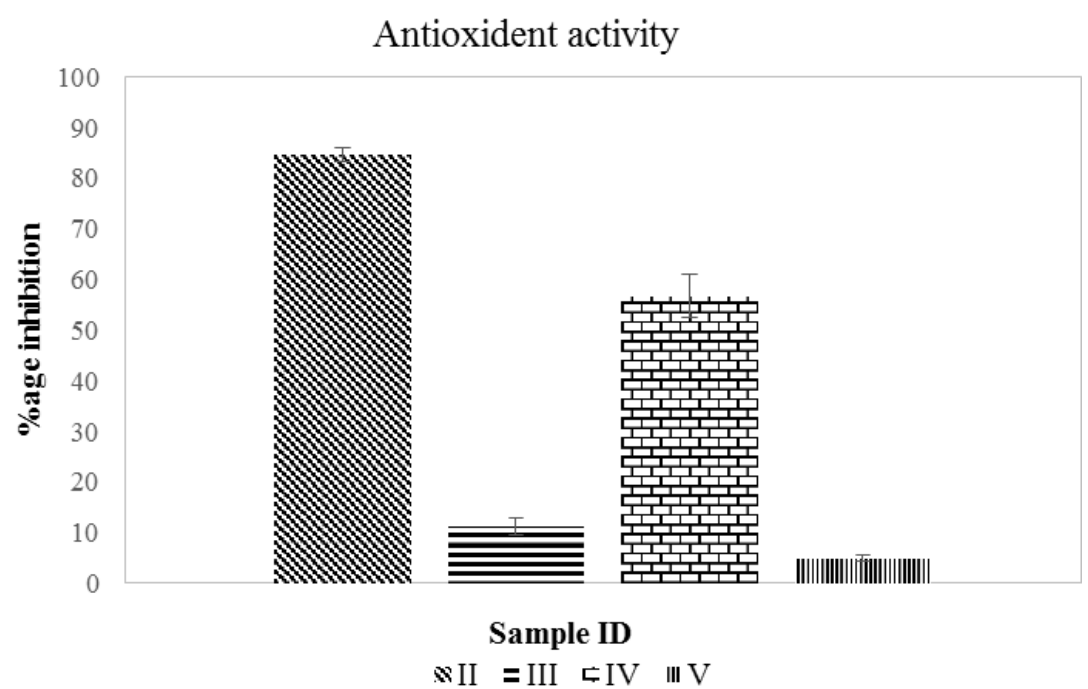

Fig. 3. Comparison of the antioxidant activity of the synthesized products 
Thus, products II and IV show better activity. Product II is still better than product IV due to the presence of phenoxy and carbonyl groups, which are more active than the benzyl group present in IV. If the results are compared for both organoselenium products, i.e., III and V, III shows better radical scavenging activity than $\mathbf{V}$ due to the same reason.

\subsubsection{Anticancer activity}

Today, cancer is the leading cause of death worldwide [26, 27]. According to an estimate in 2020, 1.8 million cancer cases and 0.60 million cancer deaths are expected in the United States of America alone [28]. Consequently, drug development for the cure of cancer is one of the leading trends in medicinal chemistry [29, 30]. The decrease in the survivability of the cancer cells in a synthesized sample ultimately exhibits the better anticancer activity of that particular compound. Figure 4 presents the comparison of anticancer activity as the percent viability of the synthesized products compared to that of the control. The results show that compounds II and III are better anticancer agents since cancer cells have less viability in the presence of these two compounds, with $40.52 \%$ and $34.45 \%$ viability, respectively, while compounds IV and $\mathbf{V}$ are moderately cytotoxic, with $64.7 \%$ and $74.6 \%$ cell viability, respectively. This may be due to the size and symmetry of the substitution on the nitrogen of the $\mathrm{N}$ heterocyclic ring $[31,32]$. If the substituted molecule is larger, it is less symmetric and has greater cytotoxicity [33]. Hence, compounds II and III are the compounds with phenoxyacetyl group as $\mathrm{N}$ substitution which contains additional acetyl group in addition to benzene ring making molecule biologically more significant.

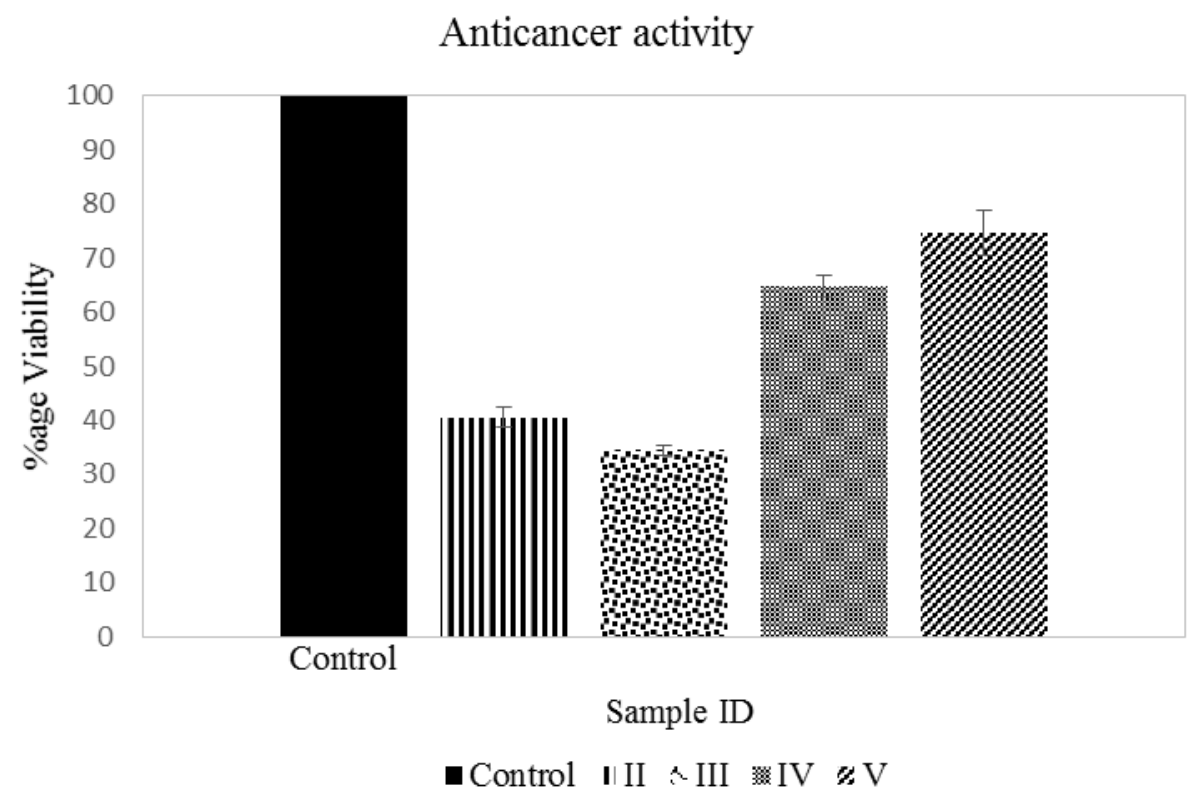

Fig. 4. Comparison of the anticancer activity of the synthesized products

\section{EXPERIMENTAL}

\subsection{Materials and methods}

All chemicals were used as received. The melting and boiling points of the synthesized compounds were determined using a Sanyo Gallenkamp MPD350 melting point apparatus. The $\lambda_{\max }$ values were calculated by ultraviolet-visible (UVvis) spectrophotometry (AE-S60 spectrophotometer). FT-IR spectral patterns were plotted with an attenuated total reflection (ATR)-based instrument, while ${ }^{1} \mathrm{H}$ NMR was recorded with a Bruker 300
$\mathrm{MHz}$ Ultrasheild spectrometer with DMSO- $d_{6}$ or deuterated chloroform $\left(\mathrm{CDCl}_{3}\right)$ as solvents. The molecular masses were calculated through the UHPLC-MS/PDA (Waters, USA) equipped with an electrospray ionization (ESI) mass spectrometer. The instrumental conditions were optimized at a capillary voltage of $0.8 \mathrm{KV}$ for both (possitve and negative) ionization modes and at a cone voltage of $15 \mathrm{~V}$ for both positive and negative scan modes, with scanning at a broad range of 300-700 Da. For chromatography, the mobile phase was a mixture of methanol and water (80:20), with a flow rate of $0.3 \mathrm{ml} /$ minute and octadecylsilyl (ODS) 
column $(50 \times 1.5 \mathrm{~mm}, 1.7 \mu \mathrm{m})$. Data were processed through Empower 3.0 software and presented in terms of the chromatogram for the total ion current (TIC), and the spectrum of both UVvisible spectra and mass spectra were obtained at major peaks.

\subsection{Synthesis of salts}

3.2.1. Synthesis of $1,1^{\prime}-(1,2-$ phenylenebis(methylene))bis(3-(2-phenoxyacetyl)1H-imidazol-3-ium) chloride (II)

Imidazole (29.4 mmol, $2.0 \mathrm{~g}$ ) was dissolved in $25 \mathrm{ml}$ of DMSO, and $\mathrm{KOH}(57.9 \mathrm{mmol}, 3.25 \mathrm{~g})$ was added. After 30 minutes of stirring, $\alpha, \alpha$ dibromo- $o$-xylene (14.5 mmol, $3.82 \mathrm{~g}$ ) was added and the mixture was refluxed for 8 hours. The refluxed product was added to $300 \mathrm{ml}$ of water. After 24 hours, $N$-alkylated product I was recovered. Finally, alkylated product I (11 mmol, $2.64 \mathrm{~g})$ was taken and phenoxy acetyl chloride $(29.0 \mathrm{mmol}$, $4.96 \mathrm{~g}$ ) was added and refluxed in $40 \mathrm{ml}$ of 1,4dioxane. The obtained solution was evaporated in at fume hood to recover NHC-containing ligand II as a thick honey-like fluid. Boiling point 143-145 ${ }^{\circ} \mathrm{C}, \lambda_{\max } 300 \mathrm{~nm}$, yield $76 \%$ (5.25 g). FT-IR (ATR, $v_{\max }, \mathrm{cm}^{-1}$ ); 691 (mono-substituted benzene), 754 (o-disubstituted benzene), $1174\left(\mathrm{C}-\mathrm{O}_{\text {ester }}\right), 1208$ (aromatic amine), $1295\left(\mathrm{C}-\mathrm{O}_{\text {phenolic }}\right), 1490\left(\mathrm{CH}_{2}\right.$ bending, s), $1548\left(\mathrm{C}=\mathrm{N}^{+}\right.$conjugating $), 1595(\mathrm{~N}-$ $\mathrm{C}=\mathrm{O}$ stretching, s), $1735(\mathrm{C}=\mathrm{O}$ stretching, $\mathrm{s})$ [34], 2400-3050 (multiple broad peaks of ammonium ion), $3056\left(\mathrm{C}-\mathrm{H}_{\text {arom }}\right.$ or benzene $), 3132(\mathrm{C}-\mathrm{H}$ stretching in imidazole). Anal. Calc. for $\mathrm{C}_{30} \mathrm{H}_{28} \mathrm{Cl}_{2} \mathrm{~N}_{4} \mathrm{O}_{4}$ : C, 53.91; H, 4.22; N, 8.38. Found: C $54.05, \mathrm{H}, 4.24 ; \mathrm{N}, 8.40$.

\subsubsection{Synthesis of $1,1^{\prime}-(1,2-$}

phenylenebis(methylene))bis(3-benzyl-1Himidazol-3-ium) chloride (IV)

Compound I ( $8.39 \mathrm{mmol}, 2.0 \mathrm{~g})$ was dissolved in $50 \mathrm{ml}$ of acetonitrile. Then, benzyl chloride $(16.6 \mathrm{mmol}, 2.11 \mathrm{~g})$ was added. After 8 hours of stirring, the obtained solution was filtered to recover the white paste-like product IV. Melting point $235-237{ }^{\circ} \mathrm{C}, \lambda_{\max }=330 \mathrm{~nm}$, yield $=72 \%$ $(4.97 \mathrm{~g})$. FT-IR (ATR, $\left.v_{\max }, \mathrm{cm}^{-1}\right) ; 713$ (monosubstituted benzene), 754 (disubstituted benzene), 1295 (aromatic amine), $1543\left(\mathrm{CH}_{2}\right.$ bending), 1574 (C-C aromatic), $1625(\mathrm{C}-\mathrm{C}), 1650(\mathrm{C}-\mathrm{N}), 2600$ 3400 (ammonium ion, multiple broad peaks), 2819 (C-H aliphatic), $2849\left(\mathrm{C}-\mathrm{CH}_{2}\right), 3050$ (benzene), $3125\left(\mathrm{C}-\mathrm{H}\right.$ imidazol), $3360\left(\mathrm{H}_{2} \mathrm{O}\right)$. Anal. Calc. for
$\mathrm{C}_{28} \mathrm{H}_{28} \mathrm{Cl}_{2} \mathrm{~N}_{4}$ : C, 68.43; H, 5.74; N, 11.40. Found: C, 68.54; H, 5.77; N, 11.42 .

\subsection{Synthesis of organoselenium compounds}

3.3.1. Synthesis of compound (1,1'-(3,3'-(1,2phenylenebis(methylene))bis(2-selenoxo-2,3dihydro-1H-imidazole-3,1-diyl))bis(2phenoxyethanone)) (III)

Salt II (1.64 mmol, $1.0 \mathrm{~g})$ was mixed in 50 $\mathrm{ml}$ of distilled water in a round bottom flask. Then, $\mathrm{Na}_{2} \mathrm{CO}_{3}$ (6.56 mmol, $0.69 \mathrm{~g}$ ) and selenium (4.92 mmol, $0.39 \mathrm{~g}$ ) were added. After refluxing for 3 hours, the hot solution was filtered. The residue was washed with chloroform and then evaporated to obtain organoselenium product IV as a white powder. Melting point $159-161{ }^{\circ} \mathrm{C}, \lambda_{\max }=330 \mathrm{~nm}$, yield $=75 \%(0.82 \mathrm{~g})$. FT-IR (ATR, $\left.v_{\max }, \mathrm{cm}^{-1}\right)$; 736 (mono-substituted benzene), 751 (o-disubstituted benzene), 1235 ( $\mathrm{C}=\mathrm{Se}$ stretching), 1291 $\left(\mathrm{C}-\mathrm{O}_{\text {phenolic }}\right), 1440 \quad\left(\mathrm{CH}_{2}\right.$ stretching $), 1457$ (Se), $1700(\mathrm{C}=\mathrm{O}, \mathrm{w}), 3116\left(\mathrm{C}-\mathrm{H}_{\text {arom }}\right.$ stretching imidazole ring). ${ }^{1} \mathrm{H}$ NMR $\left(300 \mathrm{MHz}, \mathrm{DMSO}-d_{6}\right) \delta \mathrm{ppm}$; $3.37\left(\mathrm{~s}, 4 \mathrm{H}, 2 \times \mathrm{CH}_{2}\right), 5.32\left(\mathrm{~s}, 4 \mathrm{H}, 2 \times \mathrm{CH}_{2}-\mathrm{O}\right)$, 6.96-6.93 (t, 4H, $\left.4 \times \mathrm{CH}_{\text {arom }}\right), 7.09(\mathrm{~s}, 2 \mathrm{H}, 2 \times$ $\mathrm{CH}_{\text {arom }}$ ), 7.31-7.28 (q, $J_{l}=9 \mathrm{~Hz}, J_{2}=2.4 \mathrm{~Hz}, 2 \mathrm{H}, 2$ $\left.\times \mathrm{CH}_{\text {arom }}\right), 7.71\left(\mathrm{~s}, 2 \mathrm{H}, 2 \times \mathrm{CH}_{\text {arom }}\right) \cdot{ }^{13} \mathrm{C}$ NMR $(75$ MHz, DMSO- $\left.d_{6}\right) \delta$ ppm: $34.6\left(2 \times \mathrm{CH}_{2}-\mathrm{N}\right), 46.9$ $\left(\mathrm{s}, \mathrm{CH}_{2}-\mathrm{O}\right), 120.0\left(2 \times \mathrm{CH}_{\text {arom }}\right), 130.4\left(\mathrm{CH}_{\text {arom }}\right)$, $138.6\left(\mathrm{CH}_{\text {arom }}\right), 164.5$ (s, C-Se). UPLC-MS $\left[\mathrm{CH}_{3} \mathrm{CN}\right]: \mathrm{m} / z[\mathrm{M}+1]^{+}=665.02(96.3 \%)$. Calculated for $\left[\mathrm{C}_{30} \mathrm{H}_{27} \mathrm{~N}_{4} \mathrm{O}_{4} \mathrm{Se}_{2}\right]^{+}$and found 664.98 . UVvis $\lambda_{\max }$ : 260.5, $223.8 \mathrm{~nm}$. Anal. Calc. for $\mathrm{C}_{30} \mathrm{H}_{26} \mathrm{~N}_{4} \mathrm{O}_{4} \mathrm{Se}_{2}$ : C, 54.23; H, 3.94; N, 8.43. Found: C, 54.05; H, 3.94; N, 8.40.

\subsubsection{Synthesis of compound (3,3'-(1,2- phenylenebis(methylene))bis(1-benzyl-1H- imidazole-2(3H)-selenone)) (V)}

Compound IV (2.03 mmol, $1.0 \mathrm{~g})$ was mixed in $50 \mathrm{ml}$ of distilled water in a round bottom flask. Then, $\mathrm{Na}_{2} \mathrm{CO}_{3}(9.2 \mathrm{mmol}, 0.97 \mathrm{~g})$ and selenium $(6.09 \mathrm{mmol}, 0.48 \mathrm{~g})$ were added and the reaction mixture was reflux for about 3 hours and filtered. The residue was washed with chloroform and the solvent was evaporated to obtain white crystalline organoselenium product V. Melting point $162-164{ }^{\circ} \mathrm{C}, \lambda_{\max }=350 \mathrm{~nm}$, yield $=82.5 \%$ $(1.41 \mathrm{~g})$. FT-IR (ATR, $v_{\max }, \mathrm{cm}^{-1}$ ); 732 (monosubstituted benzene), 747 (disubstituted benzene), 1235 (C=Se stretching), 1457 (Se), $1507\left(\mathrm{C}-\mathrm{C}_{\text {arom }}\right.$ stretch), 2922 (benzene ring), 3112 (C-H imidazole stretching). ${ }^{1} \mathrm{H}$ NMR (300 MHz, DMSO- $\left.d_{6}\right) \delta$ 
ppm; $3.38\left(\mathrm{~s}, 4 \mathrm{H}, 2 \times{ }^{1} \mathrm{CH}_{2}-\mathrm{N}\right), 5.32(\mathrm{~s}, 4 \mathrm{H}, 2 \times$ $\left.{ }^{2} \mathrm{CH}_{2}\right), 6.934-6.96$ (t, $\left.4 \mathrm{H}, 4 \times \mathrm{CH}_{\text {arom }}\right), 7.09(\mathrm{~s}, 2 \mathrm{H}$, $\left.2 \times \mathrm{CH}_{\text {arom }}\right), 7.31-7.28\left(\mathrm{q}, J_{1}=9 \mathrm{~Hz}, J_{2}=2.4 \mathrm{~Hz}\right.$, $\left.2 \mathrm{H}, 2 \times \mathrm{CH}_{\text {arom }}\right), 7.71\left(\mathrm{~s}, 2 \mathrm{H}, 2 \times \mathrm{CH}_{\text {arom }}\right) .{ }^{13} \mathrm{C}$ NMR $\left(75 \mathrm{MHz}, \mathrm{DMSO}-d_{6}\right) \delta \mathrm{ppm}: 38.7\left(\mathrm{Ar}-\mathrm{CH}_{2}-\right.$ $\mathrm{N}), 46.2\left(\mathrm{CH}_{2}-\mathrm{Ar}\right), 120.2\left(2 \times \mathrm{CH}_{\text {imidazole }}\right), 128.4-$ $129.2\left(\mathrm{CH}_{\text {aromatic }}\right), 135.7\left(\mathrm{CH}_{\text {benzyl }}\right), 163.08(\mathrm{~s}, \mathrm{C}-$ $\mathrm{Se})$. MS (ESI) $\left[\mathrm{CH}_{3} \mathrm{CN}\right]: \mathrm{m} / \mathrm{z}[\mathrm{M}+1]^{+}=577.21$. Calculated for $\left[\mathrm{C}_{28} \mathrm{H}_{27} \mathrm{~N}_{4} \mathrm{Se}_{2}\right]^{+}$and found 577.23. UV-vis: $\lambda_{\max }$ : $260.5,227.3 \mathrm{~nm}$. Anal. Calc. for $\mathrm{C}_{28} \mathrm{H}_{26} \mathrm{~N}_{4} \mathrm{Se}_{2}: \mathrm{C}, 58.34 ; \mathrm{H}, 4.55 ; \mathrm{N}, 9.72$. Found: C, 58.12; H, 4.54; N, 9.68 .

\subsection{Antioxidant study}

The antioxidant activity or the radical scavenging potential of the synthesized products (II, III, IV and V) were evaluated in terms of radical scavenging or hydrogen donating ability. For this purpose, 1,1-diphenyl-2-picrylhydrazyl (DPPH) was used as the reagent, which is a stable radical since the electrons delocalize over the entire molecule [35]. The DPPH molecule requires an additional electron to become a stable molecule (pale violet color), suggesting that the tested product is an anti-oxidizing agent [36].

\subsection{Anticancer activity}

The cytotoxicity of all products was evaluated against MCF-7 breast cancer cells. These cells were cultured under optimal incubator conditions in Dulbecco's Modified Eagle's Medium (DMEM). The medium was further supplemented with streptomycin $(100 \mu \mathrm{g} / \mathrm{ml})$, penicillin $(100 \mathrm{units} / \mathrm{ml})$, and $10 \%$ fetal bovine serum. The culture was maintained at $37^{\circ} \mathrm{C}$ and was supplied with $5 \% \mathrm{CO}_{2}$. A $0.05 \%$ solution of the synthesized compounds was prepared in DMSO, which was then added to the wells containing the cell culture [37].

After addition of the products to the cell culture, the microtitre plate was left over night. Then, $50 \mu \mathrm{l}$ of the 3-(4,5-dimethylthiazol-2-Y1)-2,5diphenyltetrazolium bromide (MTT) lysis solution (DMSO) was added to each well, and the plate was further incubated for about 10 minutes. Finally, the absorbance of the samples was recorded at $490 \mathrm{~nm}$ with a standard ELIZA reader. The data was analyzed to assess the effects of the test substances on cell viability [38].

\section{CONCLUSION}

New bis-imidazolium salts and their corresponding organoselenium compounds were synthe- sized and characterized by UV-vis, FT-IR and ${ }^{1} \mathrm{H}$ and ${ }^{13} \mathrm{C}$ NMR spectroscopy. The antioxidant activity of the synthesized products was checked against the DPPH radical. The results showed that the bisimidazolium salts have better activity than the corresponding organoselenium compounds. The anticancer activity was evaluated against MCF-7 (human breast adenocarcinoma cell line) using the MTT assay. All products were moderately active against cancer cells, but organoselenium product III showed the best results. Hence, imidazolium salts showed the best antioxidant activities due to the presence of acidic hydrogen, whereas organoselenium compounds showed the best anticancer activity, probably due to the presence of selenium.

Acknowledgments. The authors are thankful to the Department of Chemistry, University of Agriculture Faisalabad, Pakistan, for providing the necessary facilities to accomplish this research and to the Higher Education Commission of Pakistan (HEC-Pak) for awarding research grant NRPU-8198.

Supplementary file. A supporting information file has been provided.

Conflict of interest statement. The authors declare no conflict of interest.

\section{REFERENCES}

[1] S. C. Sau, P. K. Hota, S. K. Mandal, M. Soleilhavoup, G. Bertrand, Stable abnormal N-heterocyclic carbenes and their applications, Chem. Soc. Rev., 49, 1233-1252 (2020).

[2] D. Zhu, L. Chen, H. Fan, Q. Yao, S. Zhu, Recent progress on donor and donor-donor carbenes, Chem. Soc. Rev., 49, 908-950 (2020).

[3] M. Fevre, J. Pinaud, Y. Gnanou, J. Vignolle, D. Taton, $\mathrm{N}$-Heterocyclic carbenes (NHCs) as organocatalysts and structural components in metal-free polymer synthesis, Chem. Soc. Rev., 42, 2142-2172 (2013).

[4] L. Benhamou, E. Chardon, G. Lavigne, Sp. BelleminLaponnaz, V. Cesar, Synthetic routes to N-heterocyclic carbene precursors, Chem. Rev., 111, 2705-2733 (2011).

[5] L. Falivene, L. Cavallo, Theoretical NMR spectroscopy of N-heterocyclic carbenes and their metal complexes, Coord. Chem. Rev., 344, 101-114 (2017).

[6] M. Elsherbini, W. S. Hamama, H. H. Zoorob, Recent advances in the chemistry of selenium-containing heterocycles: five-membered ring systems, Coord. Chem. Rev., 312, 149-177 (2016).

[7] H-J. Sun, B. Rathinasabapathi, B. Wu, J. Luo, L-P. Pu, L.Q. Ma, Arsenic and selenium toxicity and their interactive effects in humans, Environ. Int. 69, 148-158 (2014).

[8] A. G. Vogt, G. T. Voss, R. L. de Oliveira, J. J. Paltian, L. F. Duarte, D. Alves et al. Organoselenium group is critical for antioxidant activity of 7-chloro-4-phenyl- 
selenyl-quinoline, Chem. Biol. Interact., 282, 7-12 (2018).

[9] A. Ecker, R. S. da Silva, M. M. dos Santos, D. ArdissonAraújo, O. E. Rodrigues, J. B. T. da Rocha et al., Safety profile of AZT derivatives: Organoselenium moieties confer different cytotoxic responses in fresh human erythrocytes during in vitro exposures, J. Trace Elem. Med. Biol., 50, 240-248 (2018).

[10] J. Fernández-Lodeiro, M. F. Pinatto-Botelho, A. A. Soares-Paulino, A. C. Gonçalves, B. A. Sousa, C. Princival et al., Synthesis and biological properties of seleniumand tellurium-containing dyes, Dyes Pigm., 110, 28-48 (2014).

[11] N. N. Kharabayev, Quantum chemical simulation of hexa-, penta- and tetracoordination modes in stereoisomers of the $\mathrm{Co}(\mathrm{II})$ and $\mathrm{Ni}(\mathrm{II})$ bis(ligand) complexes based on (N,O,S(Se))-tridentate azomethines, Russ. J. Coord. Chem., 45, 573-584 (2019). DOI: $10.1134 / \mathrm{s} 1070328419080050$.

[12] M. S. Gularte, J. M. Anghinoni, L. Abenante, G. T. Voss, R. L. de Oliveira, R. A. Vaucher et al., Synthesis of chitosan derivatives with organoselenium and organosulfur compounds: Characterization, antimicrobial properties and application as biomaterials, Carbohydr. Polym., 219, 240-250 (2019).

[13] G. Spengler, M. Gajdács, M. A. Marć, E. DomínguezÁlvarez, C. Sanmartín, Organoselenium compounds as novel adjuvants of chemotherapy drugs - a promising approach to fight cancer drug resistance, Molecules., 24, 336-338 (2019).

[14] Z. Chen, H. Lai, L. Hou, T. Chen, Rational design and action mechanisms of chemically innovative organoselenium in cancer therapy, Chem. Commun., 56, 179-196 (2020).

[15] A. R. Patra, S. Hajra, R. Baral, S. Bhattacharya, Use of selenium as micronutrients and for future anticancer drug: a review. $\mathrm{Nucl}$. 2019, 1-12 (2019).

DOI: $10.1007 / \mathrm{s} 13237-019-00306-\mathrm{y}$

[16] M. Adly, E. Gedawy, A. El-Malah, F. El-Telbany, Synthesis and anticancer activity of certain selenophene derivatives, Russ. J. Org. Chem., 55, 1189-1196 (2019).

[17] E. Fragoso, R. Azpiroz, P. Sharma, G. Espinosa-Pérez, F. Lara-Ochoa, A. Toscano et al., New organoselenium compounds with intramolecular $\mathrm{Se} \cdots \mathrm{O} / \mathrm{Se} \cdots \mathrm{H}$ interactions: NMR and theoretical studies, J. Mol. Struct. $\mathbf{1 1 5 5}$, 711-719 (2018).

[18] A. Kamal, M. A. Iqbal, H. N. Bhatti, Therapeutic applications of selenium-derived compounds, Rev. Inorg. Chem., 38, 49-76 (2018).

[19] B. Shojadoost, R. R. Kulkarni, A. Yitbarek, A. Laursen, K. Taha-Abdelaziz, T. N. Alkie et al., Dietary selenium supplementation enhances antiviral immunity in chickens challenged with low pathogenic avian influenza virus subtype H9N2, Vet. Immunol. Immunopathol., 207, 62-68 (2019).

[20] P. Chakraborty, S. S. Roy, A. Basu, S. Bhattacharya, Sensitization of cancer cells to cyclophosphamide therapy by an organoselenium compound through ROSmediated apoptosis, Biomed. Pharmacother., 84, 19921999 (2016).
[21] R. A. Haque, M. A. Iqbal, F. Mohamad, M. R. Razali, Antibacterial and DNA cleavage activity of carbonyl functionalized $\mathrm{N}$-heterocyclic carbene-silver (I) and selenium compounds, J. Mol. Struct. 1155, 362-370 (2018).

[22] A. Kamal, V. M. Nazari, M. Yaseen, M. A. Iqbal, M. B. K. Ahamed, A. S. A. Majid et al., Green synthesis of selenium-N-heterocyclic carbene compounds: Evaluation of antimicrobial and anticancer potential, Bioorg. Chem., 90, 103042 (2019). DOI: https://doi.org/10.1016/j.bioorg.2019.103042

[23] S. F. Jafari, M. B. Khadeer Ahamed, M. A. Iqbal, F. S. R. Al Suede, S. H. Khalid, R. A. Haque et al., Increased aqueous solubility and proapoptotic activity of potassium koetjapate against human colorectal cancer cells, $J$. Pharm. Pharmacol., 66, 1394-1409 (2014).

[24] R. A. Ammar, A-N. M. Alaghaz, M. E. Zayed, L. A. AlBedair, Synthesis, spectroscopic, molecular structure, antioxidant, antimicrobial and antitumor behavior of $\mathrm{Mn}(\mathrm{II}), \mathrm{Co}(\mathrm{II}), \mathrm{Ni}(\mathrm{II}), \mathrm{Cu}(\mathrm{II})$ and $\mathrm{Zn}$ (II) complexes of $\mathrm{O}_{2} \mathrm{~N}$ type tridentate chromone-2-carboxaldehyde Schiff's base ligand, J. Mol. Struct., 1141, 368-381 (2017).

[25] S. B. Kedare, R. Singh, Genesis and development of DPPH method of antioxidant assay, J. Food Sci. Technol., 48, 412-422 (2011).

[26] A. G. Heriot. Whither Anal Cancer?, Nature Publishing Group, 2020.

[27] A. P. Thrift, H. B. El-Serag, Burden of gastric cancer. Clin. Gastroenterol. Hepatol., 18, 534-542 (2020).

[28] R. L. Siegel, K. D. Miller, A. Jemal, Cancer statistics, 2020, CA: Ca-Cancer J. Clin., 70, 7-30 (2020). DOI: $10.3322 /$ caac. 21590

[29] J. Ferlay, I. Soerjomataram, R. Dikshit, S. Eser, C. Mathers, M. Rebelo et al., Cancer incidence and mortality worldwide: sources, methods and major patterns in GLOBOCAN 2012. Int. J. Cancer. 136, E359-E386 (2015).

[30] M. Krstic, B. Petković, M. Milčić, D. Mišić, J. F. Santibanez, Synthesis, characterization and biological study of new dinuclear zinc(II) and nickel(II) octaaza macrocyclic complexes, Maced. J. Chem. Chem. Eng. 38, 11 (2019). DOI: 10.20450/mjcce.2019.1599

[31] M. Atif, H. N. Bhatti, R. A. Haque, M. A. Iqbal, M. B. Ahamed Khadeer, A. M. S. A Majid, Synthesis, structure and anticancer activity of symmetrical and nonsymmetrical silver(I)-N-heterocyclic carbene complexes, Appl. Biochem. Biotechnol., 2020. DOI: $10.1007 / \mathrm{s} 12010-019-03186-9$

[32] M. Yaqoob, S. Gul, N. F. Zubair, J. Iqbal, M. A. Iqbal, Theoretical calculation of selenium N-heterocyclic carbene compounds through DFT studies: Synthesis, characterization and biological potential. J. Mol. Struct. 1204, 127462 (2020). DOI: https://doi.org/10.1016/j.molstruc.2019.127462.

[33] M. A. Iqbal, R. A. Haque, S. F. Nasri, A. A. Majid, M. B. K. Ahamed, E. Farsi et al., Potential of silver against human colon cancer: (synthesis, characterization and crystal structures of xylyl (ortho, meta, \& para) linked bisbenzimidazolium salts and $\mathrm{Ag}(\mathrm{I})-\mathrm{NHC}$ complexes: In vitro anticancer studies). Chem. Cent. J. 7, 1-27 (2013). 
[34] M. Refat, S. Abdel-Hafez, Synthesis and spectroscopic studies of the new Ag (I) organoselenium complex. Russ. J. Gen. Chem. 86, 1151-1153 (2016).

[35] F. Al-Khodir, Synthesis, spectroscopic interpretations, and antioxidant efficiency of two vital selenium complexes, Acta Phys. Pol., A. 132, 1265-1271 (2017).

[36] A. M. Al-Majid, S. Yousuf, M. I. Choudhary, F. Nahra, S. P. Nolan, Gold-NHC complexes as potent bioactive compounds, Chemistry Select. 1, 76-80 (2016).
[37] R. A. Haque, S. Y. Choo, S. Budagumpi, M. A. Iqbal, A. A.-A. Abdullah, Silver(I) complexes of mono- and bidentate N-heterocyclic carbene ligands: Synthesis, crystal structures, and in vitro antibacterial and anticancer studies, Eur. J. Med. Chem. 90, 82-92 (2015).

[38] R. A. Haque, M. A. Iqbal, P. Asekunowo, A. A. Majid, M. B. K. Ahamed, M. I. Umar et al, Synthesis, structure, anticancer, and antioxidant activity of para-xylyl linked bis-benzimidazolium salts and respective dinuclear $\mathrm{Ag}(\mathrm{I}) \mathrm{N}$-heterocyclic carbene complexes (Part-II), Med. Chem. Res. 22, 4663-4676 (2013). 